\title{
Modelling the Sensitivity of Zimbabwean Commercial Banks' Non-performing Loans to Shocks in Macro-economic Variables and Micro-economic Variables: (2009-2014)
}

\author{
Jacob Muvingi $^{1}$, Kudzai Sauka ${ }^{1}$, David Chisunga ${ }^{2}$, Crispen Chirume ${ }^{2}$ \\ ${ }^{1}$ Department of Financial Engineering, Harare Institute of Technology, Harare, Zimbabwe \\ ${ }^{2}$ Department of Forensic Accounting and Auditing, Harare Institute of Technology, Harare, Zimbabwe
}

Email address:

muvingij@gmail.com (J. Muvingi), kudzysauka@gmail.com (K. Sauka), dchisunga@gmail.com (D. Chisunga), krisspinc@gmail.com (C. Chirume)

\section{To cite this article:}

Jacob Muvingi, Kudzai Sauka, David Chisunga, Crispen Chirume. Modelling the Sensitivity of Zimbabwean Commercial Banks' Nonperforming Loans to Shocks in Macro-economic Variables and Micro-economic Variables: (2009-2014). International Journal of Economic Behavior and Organization. Vol. 5, No. 4, 2017, pp. 92-99. doi: 10.11648/j.ijebo.20170504.12

Received: April 27, 2017; Accepted: June 2, 2017; Published: October 21, 2017

\begin{abstract}
This paper used complementary panel data models that are fixed effect regression model and panel vector auto regression model. The study was motivated by the hypothesis that both macroeconomic and microeconomic variables have an effect on the loan quality. The first part of the research was to determine the specific macro and microeconomic variables that give rise to the non-performing loans (NPLs) using fixed effect regression model. The empirical findings of this study provide evidence that nonperforming loans depends on macro and micro economic variables, the trend analysis of Zimbabwean commercial banks' shows an upward movement of over the period of study. The study found out that Gross domestic product (GDP), Inflation, loan deposit ratio and bank size had a statistical significant effect on the level of non-performing loans (NPLs). The second part was mainly to model the dynamic relationship of all the variables that were found to affect nonperforming loans (NPLs); this was done through impulse response analysis based on PANEL VAR model. One standard shock to credit growth will be greatly felt in the sixth year, whereas of size of the bank will have a great negative impulse in the seventh year.
\end{abstract}

Keywords: Non-performing Loans, Panel Data, Panel VAR, Individuality, Impulse Response

\section{Introduction}

The deterioration in the quality of the loan portfolio of banks is the main cause of problems in the banking system of developed as well as developing economies (Jouini and Messai, 2013). The challenges being faced by the Zimbabwean banking sector largely mirror the macroeconomic constraints in the economy. Reserve Bank of Zimbabwe (January 2015 Monetary Policy Statement) revealed that credit risk and liquidity constraints remains the most significant challenge facing the banking sector.

Given the fact that changes within macroeconomic and microeconomic environment translate themselves into changes in the quality of a loan portfolio, the aim of this paper was to model the sensitivity of Zimbabwean commercial banks' nonperforming loans to shocks in the macroeconomic and microeconomic environment.

\section{Objectives of the Study}

The main objective of the study was to model the sensitivity of Zimbabwean commercial banks' nonperforming loans to shocks in macroeconomic variables and microeconomic variables and the supporting secondary objectives are as follows:

(1) To Determine the (Microeconomic Variables) Bank 
Specific Determinants of Nonperforming Loans (NPLs) of Commercial Banks in Zimbabwe.

(2) To Determine the Macroeconomic Determinants of Nonperforming Loans (NPLs) of Commercial Banks in Zimbabwe.

\section{Background of the Study}

Zimbabwe banking sector has been experiencing a perennial problem of high non-performing loans since the dollarization of the economy in 2009. The average nonperforming loans ("NPLs") ratio stood at $16 \%$ as at 31 December 2014, 4\% down from 30 June 2014.

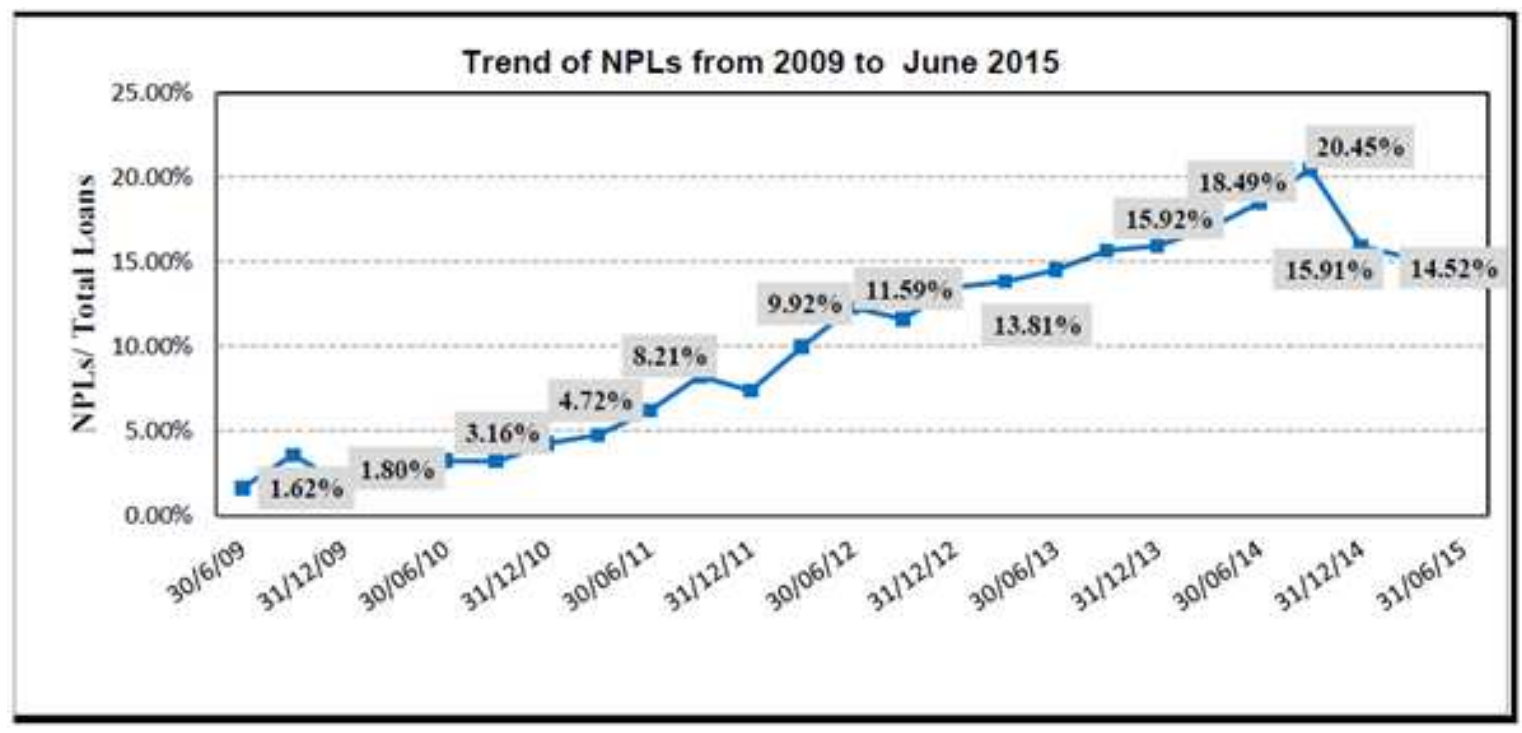

Source: July 2015 Mid-Term Monetary Policy Statement

Figure 1. Trend of NPLs from 2009 to June 2015.

During the last half of 2014 the non-performing loan ratio dropped by 453 basis points to $15.91 \%$, the decline in the NPL ratio noted over the quarter was largely attributable to the closure of Interfin and Allied banks' and general improvement in loan quality in a few banks. The Reserve Bank closed two banking institutions, namely, Capital Bank Limited and Interfin Banking Corporation. It cancelled Allied Bank Limited's banking licence on 8 January 2015. Consequently, the number of distressed banks in the sector went down to three, Metbank, Afrasia Bank Zimbabwe Limited and Tetrad Investment Bank. With the prevalence of high NLP ratio these banks continued to experience some liquidity and solvency challenges. (January 2015 Monetary Policy Statement)

\section{Empirical Literature}

\subsection{Macroeconomic Determinants of NLP}

The analysis of macroeconomic variable as determinants of NLP has put sovereign debt under scrutiny. Reinhart \& Rogoff (2010) took their time to study the transmission of sovereign debt to the banking system. They provide empirical evidence that banking crises most often either precede or coincide with sovereign debt crises and later identified two channels of transmission of a sovereign debt crisis to the banking system, the first one being the 'ceiling' effect on the market evaluation of credibility for the national banks due to the deterioration of public finances resulting in banks being exposed to liquidity challenges. In efforts to reduce liquidity risks banks tend to reduce lending leading to debtors being unable to refinance their debt. Louzis (2011) formulated: Sovereign debt hypotheses, thus: Rising sovereign debt leads to an increase in NPLs.

Sales and Saurina (2002) used Spanish banks panel data over the period of 1985-1997 and employed dynamic model to investigate the determinants of NPLs. Fluctuations in NPLs was found to be explained by growth in GDP, bank size, market power, rapid credit expansion and capital ratio. (Rajan \& Dhal; 2003) studied Indian banks using panel regression models to suggest that credit terms have a significant effect on the Indian non-performing loans in the presence of bank size induced risk preferences and macroeconomic shocks. The changes in the cost of credit in terms of expectations of higher interest rates induce a rise in NPLs.

Nkusu (2011) analysed NPL determinants and feedback effects for a panel of 26 advanced economies. The findings are in line with previous studies and expectations. They confirm that deterioration in the macroeconomic environment (peroxide by slower growth, higher unemployment or falling asset prices) is associated with debt service problems, reflected into rising NPLs.

\subsection{Microeconomic Determinants of NLP (Bank Specific Variables)}

Klein (2013), in their research "Non-Performing Loans in CESEE: Determinants and Impact on Macroeconomic Performance "investigated the non-performing loans (NPLs) 
in Central, Eastern and South- Eastern Europe (CESEE) in the period of 1998-2011. They employed Panel VAR in their analysis and found out that the level of NPLs can be attributed to both macroeconomic conditions and banks' specific factors however bank's specific factors seems to have a relatively low explanatory power. While NPLs were found to respond to macroeconomic conditions, such as GDP growth, unemployment, and inflation, the analysis also indicates that there are strong feedback effects from the banking system to the real economy, thus suggesting that the high NPLs that many CESEE countries currently face adversely affect the pace economic recovery.

Shingjergji (2013) conducted study on the "impact of bank specific factors on NPLs in Albanian banking system". In the study, capital adequacy ratio, loan to asset ratio, net interest margin, and return on equity were considered as a determinant factor of NPLs. The study utilized simple regression model for the panel data from 2002 to 2012 period and found as capital adequacy ratio has negative but insignificant whereas ROE and loan to asset ratio has negative significant effect on NPLs. The study justifies that an increase of the CAR will cause a reduction of the NPLs ratio. Besides, an increase of ROE will determine a reduction of NPLs ratio.

E. M Musau (2014); In his research "Modeling NonPerforming Loans in Kenya Commercial Banks", used a dynamic econometric model to link and assess the joint relationship between Nonperforming loan ratio and its determinants in Kenya Banking sector. The author found out that there was a positive relationship between inflation rate, Rear Interest rate, credit growth, liquidity of the bank and nonperforming loan among Commercial Banks in Kenya. The relationship between Gross domestic product, capital adequacy and non-performing loans was found to be negative.

\section{Research Methodology}

The study adopted a descriptive panel data research design. It focussed on modelling non-performing loans in Zimbabwe from the empirical evidences that help answer the research objective the study made use of commercials' loan books and all the aggregate data pertaining non-performing loans in the commercial banking system.

\subsection{Sample Population}

The researcher selected 7 senior commercial banks in Zimbabwe judgmentally, basically on the fact that all of them where in existence from 2009 up December 2014. The sample consists of three private domestic-owned banks namely: Commercial Bank of Zimbabwe (CBZ), First Banking Corporation (FBC), NMB, one state owned bank (ZB Bank formerly Zimbank), and three foreign-owned banks, namely: Barclays bank, Standard Chartered Bank and Stanbic bank.

\subsection{Model Specification}

To explain relationship between macroeconomic variables and bank specific variables Non-Performing Loans (NPL) panel data regression models were used to analyse and quantify the sensitivity of the NPLs to macroeconomic and financial variables described above during the period between the Q1: 2009 and Q1: 2014. A second issues lies in studying the dynamic response of one variable to changes in another. In this paper, a panel vector autoregressive (panel VAR) model was later utilised. The VAR deals with the issue of simultaneity bias, by assuming all variables under study are endogenous. It also describes the dynamic evolution of a number of variables from their common history.

\subsubsection{Explanation of Study Variables}

Microeconomic variables: Loan to deposit ratio (LDR), Return on assets (ROA), bank size (SIZE) and credit growth (CG)

Macroeconomic variables: Public debt as \% of GDP (DEBT), Annual percentage growth rate of GDP (GDP), Annual average inflation rate (INFL), \% of unemployment (UNEMP) and Average Lending rate (LR)

Dependent Variable: Non-performing loan

\subsubsection{Fixed Effect and Random Effects Models}

Fixed effects and random effects models work to remove omitted variable bias by measuring change within a group. By measuring within a group (across time) you control for a number of potential omitted variables unique to the group. When one intends to use fixed effects or random effects models, he or she should take into account their assumption.

Fixed and Random effect regression model

$$
y_{i t}=\beta_{0}+X_{i t} \beta+Z_{t} \gamma+\alpha_{i}+\mu_{i t}
$$

Where:

$\mathrm{y}_{i t}=$ the dependent variable observed for individual $i$ in time $t$.

$\mathrm{X}_{i t}=$ the time-variant specific regressor

$\mathrm{Z}_{t}=$ the time-variant common regressor

$\alpha_{i}=$ the unobserved individual effect

$\mathrm{u}_{i t}=$ the error term

Choosing between fixed and random effects

When analysing panel data with fixed and random effects model, one of these models will be inconsistence hence there is a need to choose the best model between the two. In this study The Hausman test was used as a criteria to select the best model to use.

Modified panel regression model for the study:

This model links the ratio of NPLs to total loans and key macro-economic and bank-specific variables. By considering both sets of variables the specification of the fixed effect panel regression model is constructed as follows.

$$
\begin{gathered}
N P L s_{i t}=\beta_{1, i}+\beta_{2} D E B T_{t}+\beta_{3} G D P_{t}+\beta_{4} I N F L_{t}+\beta_{5} U N E M P_{t}+\beta_{6} L R_{t}+\beta_{7} L D R_{i t}+\beta_{8} C G_{i t}^{h}+\beta_{9} T L I_{i t}+\beta_{10} S I Z E_{i t}+ \\
\beta_{11} R 0 A_{i t}+\beta_{12} N P L_{i t-1}+\eta+\mu_{i t}
\end{gathered}
$$


Where:

$N P L s_{i t}=$ ratio of NPLs to total loans for bank $i$ in year $t$

$D E B T_{t}=$ government debt to GDP ratio at time $t$

$I N F L_{t}=$ annual average inflation at time $t$

$U N E M P_{t}=\%$ of unemployment at time $t$

Bank specific variables

$L D R_{i t}=$ the loans to deposit ratio in time period $t$ for bank

$C G_{i t}^{h}=$ the credit growth in time period $t$ for $\mathrm{bank}_{i}$, as a percentage of $h$

$S I Z E_{i t}=$ the ratio of relative market share of bank $i$ 's deposits that capture the size of the institution at time

$R 0 A_{i t}=$ the return on assets in time period $t$ for bank $i$

$N P L_{i t-1}=$ NPLs of bank $i$ in year $t-1$

Panel VAR(Vector Auto Regression)

A panel vector autoregressive (PVAR) estimation that helps identify how variables in the system respond to shock affecting other variables. The main objective of the study was to model the sensitivity of Zimbabwean commercial banks' non-performing loans to shocks in macroeconomic variables and microeconomic variables (bank specification), hence the results of the fixed / random effect model were merged with panel vector autoregressive (PVAR) model that extract the relationship between some macroeconomics variables systematically. This model can indicate the mechanism effects of any shock and can be used in estimation an out-ofsample simulation of NLP for banking system under different scenarios.

The panel vector model of the form below was used in the study

$$
Y_{i t}=\varphi_{0}+\sum_{x=1}^{n} \varphi_{x} Y_{i, t-x}+\tau_{i}+\epsilon_{i t}
$$

\section{Data Presentation and Analysis}

The data was analysed using R-statistical package version 3.2.4 and EViews 7. The first section of this study was mainly about data preparation, explanation of study variables, and discussion of results.

\subsection{Descriptive Statistics}

Table 1. Descriptive Statistics of study variables.

\begin{tabular}{|c|c|c|c|c|c|c|c|c|c|c|}
\hline Column1 & UNEMP & SIZE & ROA & NPL & LR & LDR & INFL & GDP & DEBT & $\mathbf{C G}$ \\
\hline Mean & 0.0555 & 0.143888 & 0.031822 & 0.088247 & 0.201667 & 0.963927 & 0.149576 & 0.08027 & 0.68233 & 1.286483 \\
\hline Median & 0.054 & 0.097565 & 0.024688 & 0.02664 & 0.19375 & 0.641839 & 0.038107 & 0.08275 & 0.668 & 0.149206 \\
\hline Maximum & 0.064 & 0.493075 & 0.369031 & 0.704681 & 0.3063 & 8.332968 & 0.742982 & 0.11905 & 0.77 & 37.28799 \\
\hline Minimum & 0.053 & 0.016559 & -0.018098 & 0.000546 & 0.1312 & 0.166371 & 0.013387 & 0.03848 & 0.601 & -0.853922 \\
\hline Std. Dev. & 0.003909 & 0.118637 & 0.0565 & 0.147686 & 0.053153 & 1.544758 & 0.268785 & 0.03379 & 0.06178 & 5.764506 \\
\hline Skewness & 1.66634 & 1.71495 & 5.200082 & 2.834685 & 0.901978 & 4.087369 & 1.78317 & -0.0616 & 0.27468 & 6.010199 \\
\hline Kurtosis & 3.976187 & 4.783062 & 31.75569 & 10.98355 & 3.171881 & 18.57927 & 4.189957 & 1.17142 & 1.62472 & 38.0166 \\
\hline Probability & 0.000026 & 0.000002 & 0 & 0 & 0.056511 & 0 & 0.000004 & 0.05292 & 0.14675 & 0 \\
\hline Sum & 2.331 & 6.043283 & 1.336521 & 3.706356 & 8.47 & 40.48494 & 6.282176 & 3.37143 & 28.658 & 54.03227 \\
\hline Sum Sq. Dev. & 0.000626 & 0.57706 & 0.130883 & 0.894263 & 0.115834 & 97.83737 & 2.962059 & 0.04682 & 0.15647 & 1362.411 \\
\hline Observations & 42 & 42 & 42 & 42 & 42 & 42 & 42 & 42 & 42 & 42 \\
\hline
\end{tabular}

The values for non-performing loans range from $0.55 \%$ to a maximum of $74.3 \%$. It has a mean of $20.26 \%$ and also recorded a standard deviation of $14.76 \%$. Debt values ranges from a minimum of $60.1 \%$ to a maximum $70 \%$, it has a mean of $68.2 \%$ and a standard deviation of $6.1 \%$, These values indicate that the government expenditure is heavily financed by debt that has affected the Central bank to be the lender of last resort since it has a high load of debt of itself, causing it to borrow from local banks, thus magnifying the liquidity crisis. The GDP growth rate recorded a maximum of $11.91 \%$ and the lowest of $3.848 \%$, and a mean of $8.02 \%$, as far as inflation is concerned, a maximum of $74.3 \%$ and a minimum of $1.33 \%$, Which is an indication of falling of prices due to adoption of multi-currency.
Regarding loan rate, the maximum was $30.63 \%$ and minimum was $13.12 \%$, which is an indication of high lending rates in the market. Commercial banks credit growth rate had a maximum of $372.87 \%$ and a minimum of $-85.4 \%$, and a mean of $128 \%$. Loan-to deposit ratio (LTD) ranges from minimum of $16.63 \%$ to a maximum of $833.3 \%$. Commercial banks' Return on Assets (ROA) recorded a minimum of $0.0546 \%$ and maximum of $70.4 \%$ with a mean value of $3.18 \%$.

\subsection{Estimation of the Model}

Fitted panel fixed effect model

$$
\begin{array}{r}
N P L s_{i t}= \\
0.0689_{\text {barclays }}-0.121_{c b z}+0.271_{\text {zbbank }}+0.147_{f b c}+0.228_{n m b}+0.04167_{\text {stanbic }}+0.0321_{\text {stanchard }}(-0.798) G D P_{t}- \\
(0.11) I N F L_{t}-(0.07) L D R_{i t}+(1.73) S I Z E_{i t}
\end{array}
$$

Hausman test

The suitability of the two models was tested through
Hausman test. The results of the test show that one of the model between the two is inconsistence, hence at 95 level of 
significance test it can be concluded that random effect model is the model that is inconsistence since the $p$-value $(0.7562)$ is greater than 0.05

Analysis of the fixed effect model results

After choosing fixed effect model, the researcher went on to account for the individuality of each bank by letting the intercept vary for each bank. The purpose of this process was to incorporate the differences among the banks, which may arise through different philosophies and management styles. The researcher adopted a model that was brought forward by Gujarati (2004)

$$
Y_{i t}=\beta_{1 t}+\beta_{2} X_{2 i t}+\beta_{3} X_{3 i t}+\mu_{i t}
$$

To allow the intercept to vary among the banks the researcher made use of the differentiated intercept dummies technique.

In this case the equation (6) above becomes

$$
\begin{gathered}
Y_{i t}=\alpha_{1}+\alpha_{2} D_{2 I}+\alpha_{3} D_{3 i}+\alpha_{4} D_{4 i}+\alpha_{5} D_{5 i}+\alpha_{6} D_{6 i}+ \\
\alpha_{7} D_{7 i}+\beta_{k} B_{i t}+\gamma_{k} M_{t}
\end{gathered}
$$

Where D1, D2, D3, D4, D5, D6 and D7 represents the dummy variables of CBZ, ZB bank, FBC bank, NMB bank, Stanbic and Stanchart respectively. Hence $\alpha_{1}$ represents the intercept of Barclays bank, whereas $\alpha_{2}, \alpha_{3}, \alpha_{4}, \alpha_{5}, \alpha_{6}$ and $\alpha_{7}$, are the differential intercept coefficients, which reflect how much the intercept of CBZ, ZB bank, FBC bank, NMB bank, Stanbic bank and Standard Chartered bank, differ from the intercept of Barclays. $B_{i t}$ represents microeconomic variables and $M_{t}$ represents macroeconomic variables.

\subsection{Macroeconomic Variables and Non-performing Loans}

Two of the macro-economic variables, GDP and inflation were found to have a significant impact on determining the NPL ratio in banks. The variable GDP per capita has a negative sign meaning that a continued economic recession and downturns coupled with falling per capita GDP is likely to increase the scope of default on loans, especially in the most depressed sectors of the economies. In the most extreme cases, runs on banks during falling GDP per capita are also accompanied by a rapid decline in per capita income in real terms [World Bank (1998)]. Among the macro-economic variables, GDP had the highest $t$ value with significance of 79.7 this was in consensus with previous studies of Salas and Saurina (2002), Rajan and Dhal (2003), Jimenez and Saurina (2006) and Fofack (2005) the real growth rate of GDP is a significant predictor of credit risk faced by banks.

According to this study Inflation another macroeconomic variable which was found to be significant in explaining the dynamics of NPLs, has a $t$ value of -2.66 suggesting that it has an extensive impact on NPLs. The commercial banks average landing rate has an insignificant and negative relationship. Increase of one average interest rate leads to decrease NPL ratio by $2.09 \%$. This finding is in contradiction to other studies such as the one done by Jimenez and Saurina (2005); Quagliariello (2007) and Fofack (2005) who proposed that high interest rate increase obligation of borrowers and thus increase credit risk.

\subsection{Microeconomic Variables and Non-performing Loans}

Bank size had the greatest positive effect on nonperforming loans as highlighted by a positive and significant $t$ value of 2.593, loan deposit ratio has a negative effect of 0.07. The finding are in consensus with Louzis et al., 2010 but however contradict with the findings of (Rajan and Dhal 2003), (Salas and Saurina 2002).

The Sensitivity of Non-performing Loans to Shocks in Macro and Micro Economic Variables

After data analysis through panel fixed effect model, the variables which were found to be significant were carried further to panel VAR model to determine the dynamics of non-performing loans and their macroeconomic and microeconomic effects. As shown in the final fixed effect model above, the available variables for the panel VAR model are GDP growth, inflation, loan to deposit ratio, size and also a new variable $\left(N P L_{i t-1}\right)$ which was added into the model also credit growth (CG) and return on assets ( ROA) where included in the model, however the criteria of choosing non-significant variables (CG and ROA) was based on the magnitude of $p$-value, lending rate (LR) had a p-value of $92.48 \%$, hence it was not included.

Study Panel VAR model

$$
y_{i t}=\mu_{i}+A(L) Y_{i, t-1}+B(L) X_{t-1}+\varepsilon_{i, t}
$$

Where $y_{i t}$ is a $\mathrm{k} \times 1$ vector of all variables under consideration

$\left(Y_{t}\right.$ And $\left.X_{t}\right)$ all variables under consideration,

$\mathrm{I}=1,2,3,4 \ldots \ldots \mathrm{N}$ represents bank

$Y_{t}=\left(y_{1 t}, y_{2 t}, y_{3 t}, \ldots . y_{i t}\right)$ collects the bank specific data $\mu_{i}$ is the bank specific intercept.

$A(L)$ and $B(L)$ are lag polynomial of the VAR coefficients

$\varepsilon_{i, t}$ the disturbance with zero mean and bank specific variance

$Y_{t}=\{$ roa, size, $\operatorname{ldr}, \mathrm{cg}\}$

$X_{t}=$ collects the macroeconomic variables which do not vary across banks,

$X_{t}=\{\mathrm{Gdp}$, ifl, $\mathrm{lr}\}$

The main focus was to assess the dynamic behaviour of the model using impulse response functions, which describe the reaction of one variable in the system to innovations in another variable in the system while holding all other shocks at zero. This was done to complete the main objective of the study which was to model the sensitivity of Zimbabwean commercial banks' non-performing loans to shocks in macroeconomic variables and microeconomic variables.

\subsection{NPLs Impulse Response Function Analysis}

The graphs below shows the movement of NPLs due effect of a one standard deviation shock of selected macro and micro economic variables over a forecast of ten years as well as two red lines presenting $95 \%$ confidence interval for IRF( Interval response function)

The response of nonperforming loans to a standard deviation shock in their previous values (own effect) has a 
positive effect to the nonperforming ratio; the effect becomes statistically significant 7 years after the shock, thereafter the

trend continues on an increasing path.

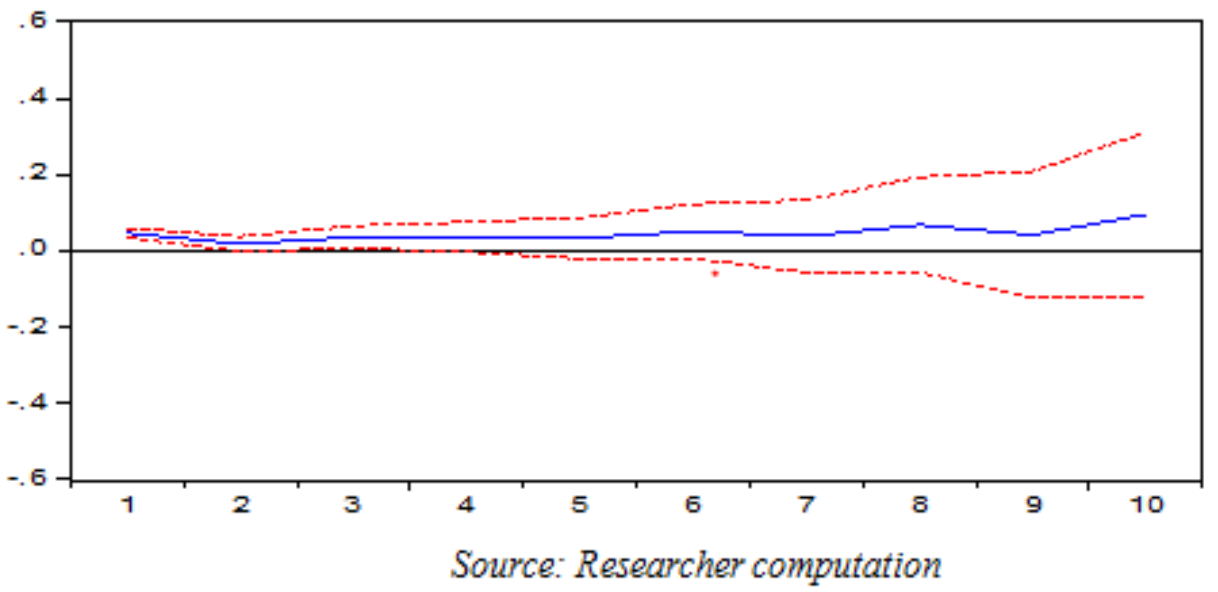

Figure 2. Response of NPLs to NPLs (Own-effect).

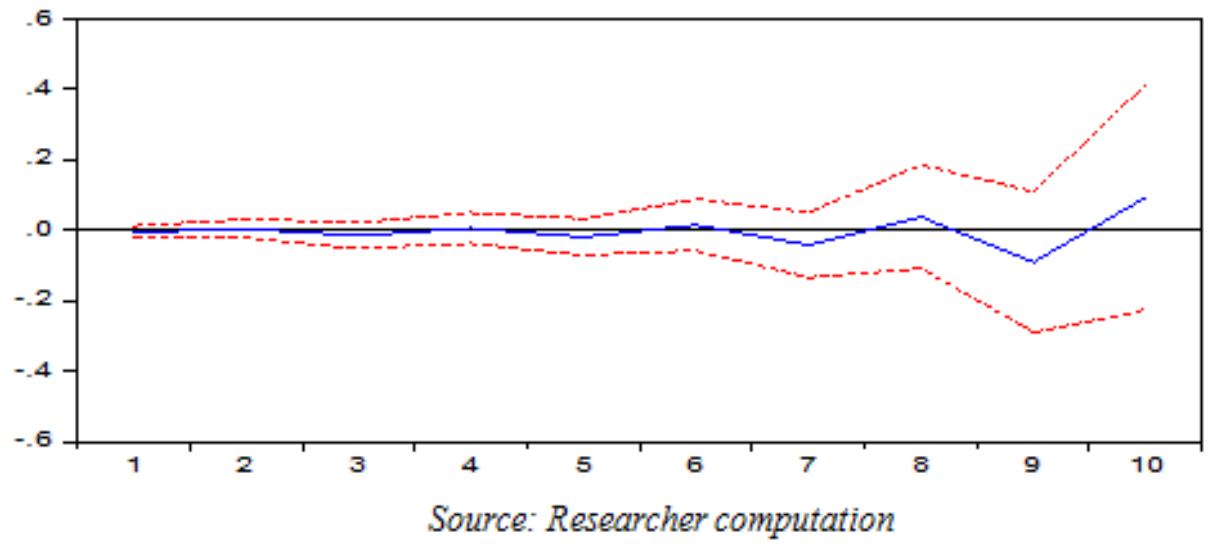

Figure 3. Response of NPLs to Inflation

From Figure 4 above it can be depicted that a standard deviation shock to inflation is insignificant in the early years just after the shock becomes significant in year 7, non-performing loans are increasing after the shock. A year later the movement take a downward direction.

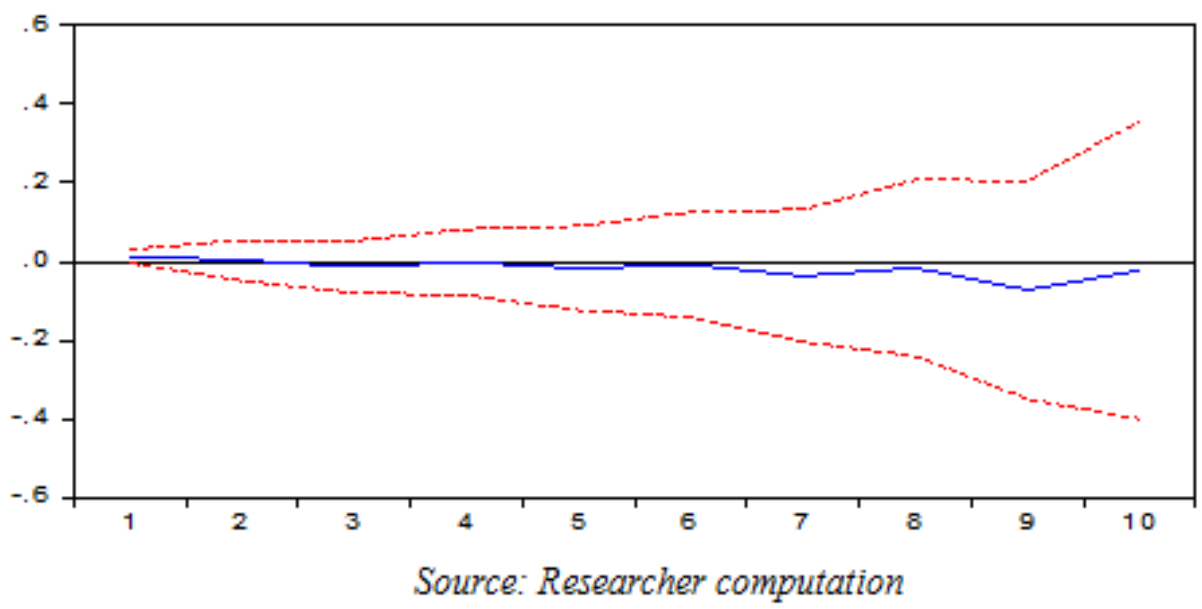

Figure 4. Response of NPLs to size of the bank.

Response of non-performing loans to banks' size depicted in Figure 4 above reveal the standard deviation shock on bank size is significant in the early years of the shock, however nonperforming loans does not quickly respond to the shock. 


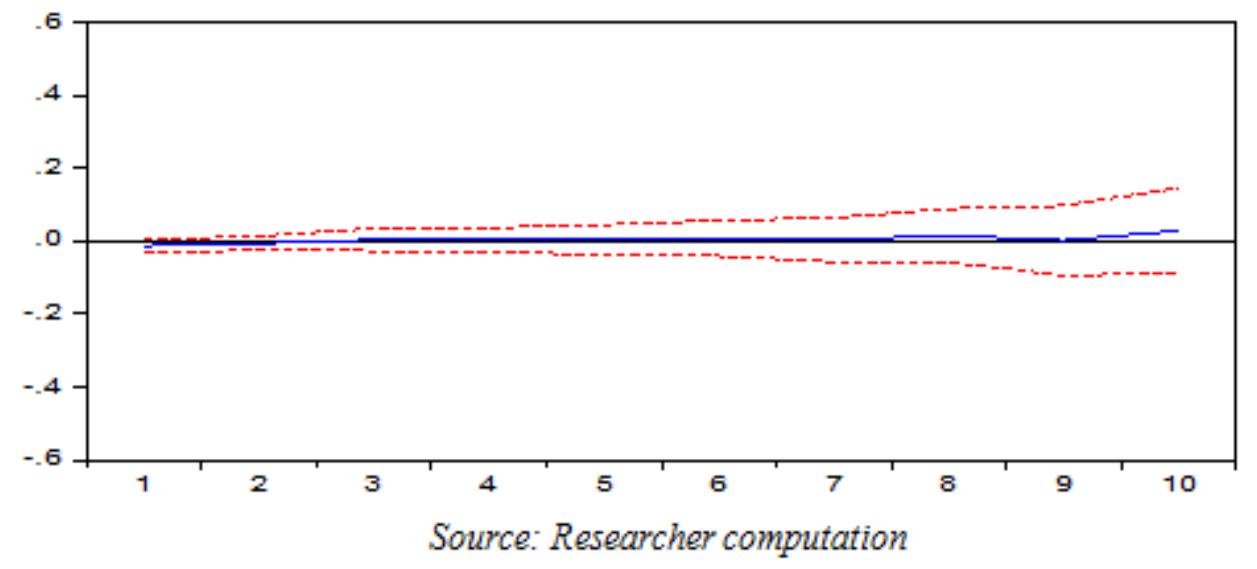

Figure 5. Response of NPLs to LDR.

Figure 5 above depicts the response of nonperforming loans to loan deposit ratio, it reflect a weak significance of one standard deviation shock to the loan deposit ratio. The levels of the nonperforming loans remain constant throughout, even after one standard deviation shock to loan deposit ratio.

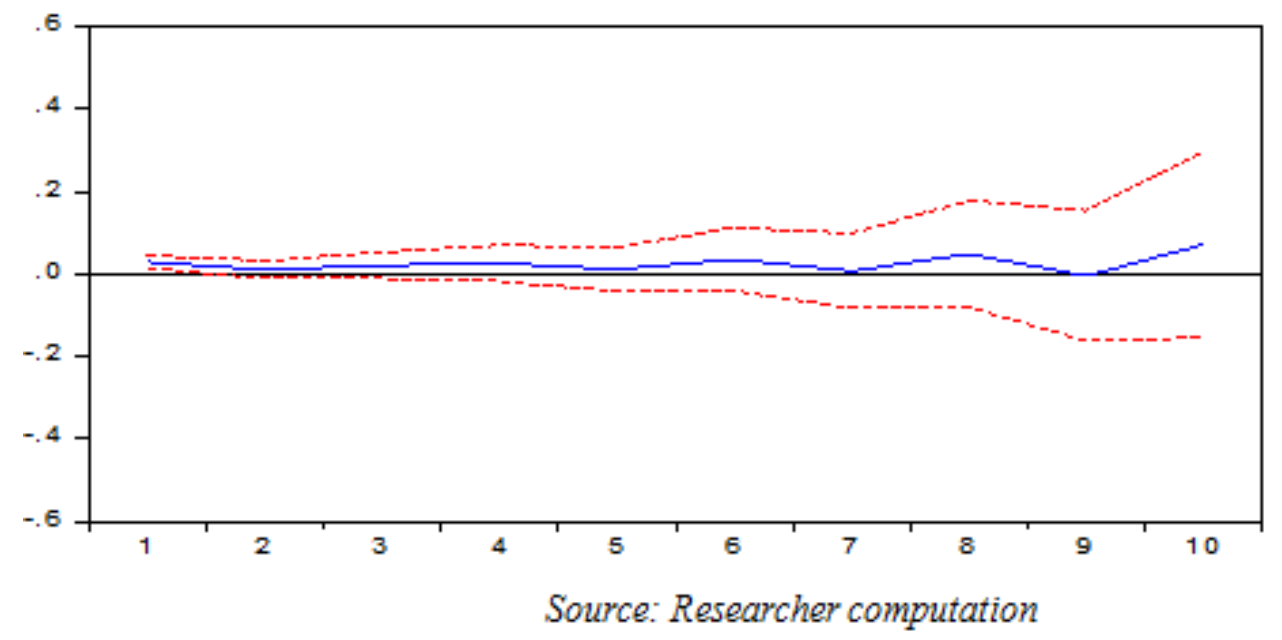

Figure 6. Response of NPLs to credit growth.

Figure 6 above shows the response of nonperforming loans to credit growth, it is shown that a one standard deviation shock to the credit growth increases nonperforming loans; the effect becomes statistically significant 6 years after the shock. After 10 years the shocks start to have a strong positive significance.

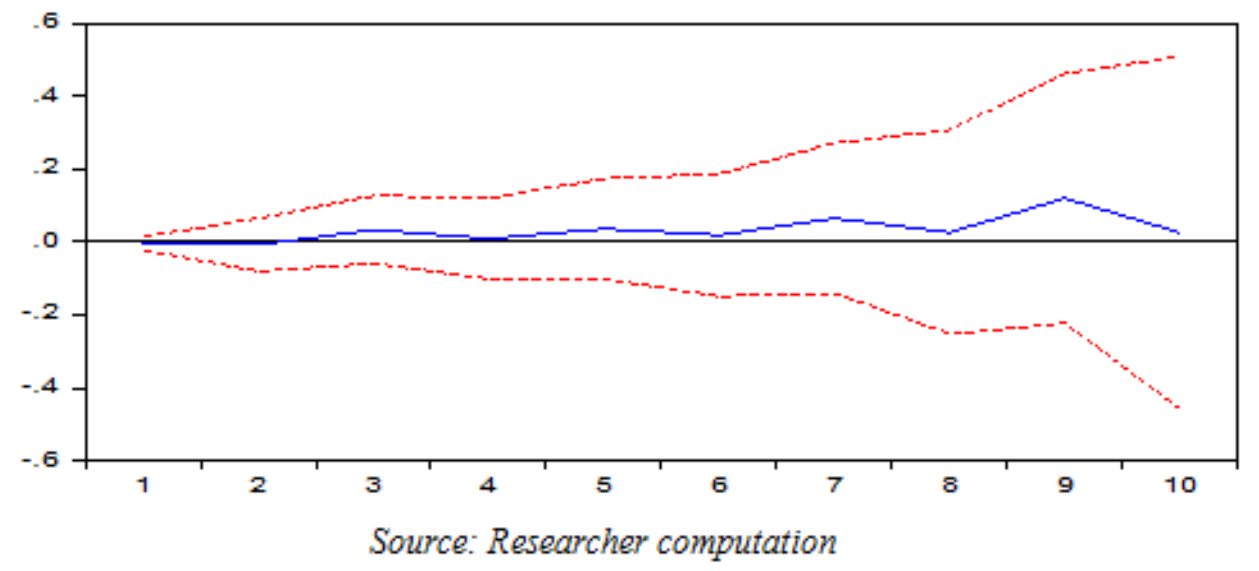

Figure 7. Response of NPLS to DROA. 
From Figure 7 above the response of nonperforming loans to return on assets above depicts a strong positive significance of one standard deviation shock to return on assets. Nonperforming loans reaches a maximum about 9 years after the initial return on assets standard deviation shock.

\section{Conclusions and Findings}

The empirical findings of this study provide evidence that nonperforming loans depends both on macro and micro economic variables, the trend analysis of Zimbabwean commercial banks' shows an upward movement of over the period of study. The study found out that GDP, Inflation, loan deposit ratio and bank size had statistically significant effect on the level of NPLs. However, the results of fixed effect regression model revealed the insignificant effect of loan to deposit ratio and inflation rate on the level of NPLs for the period under consideration.

The findings indicated that return on assets (ROA) has positive but statistically insignificant impact on NPLs. The result is unusual since normally a negative impact of NPLs on bank profitability is expected. The positive relationship between nonperforming loans and ROA is also depicted under nonperforming loans response to ROA graph. This implies that commercial banks in Zimbabwe are less incentive to increase return via in utilizing their assets.

Similarly, the study under fixed effect model, also found out that size of the bank had a positive and statistically significant impact on NPLs. under impulse response analysis, it can be depicted that the significance of a standard deviation shock to the size of the bank is felt 7 years after the shock. These finding were in consensus with Louzis et al., 2010 but however are in contradictory to the findings of Rajan and Dhal (2003), Salas and Saurina (2002).

The finding of the lending rate is also surprising, as opposed to $\mathrm{H}_{9}$ where the researcher had hypothesised that average prime lending rate of commercial banks has a positive impact on NPLs, showed negative impact however an insignificant one. This implies due to other extraneous factors, increase in lending rate reduces the levels of NPLs for commercial banks in Zimbabwe.

Furthermore, credit growth which was a proxy of procyclical credit policy hypothesis, led the researcher to conclude that credit growth results in the growth of NPLs. Although the fixed effect model showed that credit growth is insignificant to explain the variation in the NPLs, impulse response analysis showed that the significance of one standard deviation shock to credit growth is mostly felt 7 years after the shock. This can be attributed to the fact that rapid landing today has an impact on the credit quality hence resulting in high future loan problems. This was in consensus to Jimenez and Saurina (2005) who revealed that credit growth lagged four years has a positive and significant influence on the NPLs. Panel VAR also provided evidence that there is a significant relationship between the credit growth of last year as well as last of last year with the values of current year's NPLs. Panel VAR revealed that there is 0.033374 and -0.044736 for 1 and 2 years back respectively.

\section{References}

[1] Shingjergji, A. (2013), The Impact of Bank Specific Variables on the Non-Performing Loans Ratio in the Albanian Banking System, Research Journal of Finance and Accounting 4, 7, 2222-1697.

[2] Katchova, A. (2013) Panel Data Models, https://www.scribd.com/doc/297814618/Panel-Data-Modelspdf, viewed, Feb 32016.

[3] Fofack, H. (2005). NPLs in sub-Saharan Africa: Causal Analysis and Macroeconomic Implications. World Bank Policy Research Working Paper No. 3769, November.

[4] Hu, J., Li, H., \& Chiu, H. (2007). Ownership and nonperforming loans: Evidence from Taiwan banks. The Developing Economies, 42, 405-420.

[5] Jimenez, G. \& Saurina, J. (2005). Credit cycles, credit risk, and prudential regulation. Banco de Espana, January 2005.

[6] Messai, A. S. and Jouini, F. (2013). Micro and macro determinants of nonperforming loans. International. Journal of economics and financial issues, 3(4), 852-860.

[7] Louzis, D. P., Vouldis, A. T. \& Metaxas, V. L., (2011). Macroeconomic and bank-specific determinants of nonperforming loans in Greece: A comparative study of mortgage, business and consumer loan portfolios. Journal of Banking \& Finance, 36(4), 1012-1027.

[8] Nkusu, M. (2011): Nonperforming Loans and Macro Financial Vulnerabilities in Advanced Economies. IMF Working Paper 11/161 (Washington: International Monetary Fund).

[9] Rajan, R. \& C. Dhal, S. C. (2003): NPLs and Terms of Credit of Public Sector Banks in India: An Empirical Assessment. Reserve Bank of India, Occasional Papers, 24(3), 81-121,

[10] Salas, V., \& Saurina, J., (2002): Credit risk in two institutional regimes: Spanish commercial and savings banks. Journal of Financial Services Research 22, 203-224.

[11] RBZ 2009-2015; Monetary policy statements.

[12] RBZ 2010- 2014; bank supervisory reports.

[13] Klein, N., (2013): Non-Performing Loans in CESEE: Determinants and Impact on Macroeconomic Performance. IMF Working Paper WP/13/72 (European Department: International Monetary Fund).

[14] Quagliarello, M., (2007). Banks' riskiness over the business cycle: a panel analysis on Italian intermediaries. Applied Financial Economics 17, 119-138.

[15] Reinhart, C., \& Rogoff, K. (2010). From Financial Crash to Debt Crisis. NBER Working Paper 15795.

[16] Rajan, R. \& Dhal, S. (2003). Non-performing loans and terms of credit of public sectorbanks in India: an empirical assessment. Reserve Bank of India Occasional Paper 24, 81-121.

[17] Gujarati, D. N, (2004): Basic Econometrics, 4th Ed., McGraw-Hill Companies. 